\title{
New Iron(II) Spin Crossover Complexes with Unique Supramolecular Networks Assembled by Hydrogen Bonding and Intermetallic Bonding
}

\author{
Takashi Kosone ${ }^{1, *(0)}$, Itaru Tomori ${ }^{2}$, Daisuke Akahoshi ${ }^{3}$, Toshiaki Saito ${ }^{3}$ and \\ Takafumi Kitazawa ${ }^{3}$ (D) \\ 1 Department of Creative Technology Engineering Course of Chemical Engineering, Anan College, 265 Aoki, \\ Minobayashi, Anan, Tokushima 774-0017, Japan \\ 2 Department of Chemistry, Faculty of Science, Toho University, 2-2-1 Miyama, Funabashi, Chiba 274-8510, \\ Japan; synapse_yf@yahoo.co.jp \\ 3 Department of Physics, Faculty of Science, Toho University, 2-2-1, Miyama 274-8510, Japan; \\ daisuke.akahoshi@sci.toho-u.ac.jp (D.A.); saito@ph.sci.toho-u.ac.jp (T.S.); \\ kitazawa@chem.sci.toho-u.ac.jp (T.K.) \\ * Correspondence: kosone@anan-nct.ac.jp; Tel.: +81-884-23-7195
}

Received: 25 September 2018; Accepted: 20 October 2018; Published: 5 November 2018

\begin{abstract}
Two spin crossover (SCO) coordination polymers assembled by combining Fe $\mathrm{Fe}^{\mathrm{II}}$ octahedral ion, 4-cyanopyridine (4-CNpy) and $\left[\mathrm{Au}(\mathrm{CN})_{2}\right]^{-}$liner unit are described. These compounds, $\mathrm{Fe}(4-\mathrm{CNpy})_{2}\left[\mathrm{Au}(\mathrm{CN})_{2}\right]_{2} \cdot 1 / 2(4-\mathrm{CNpy})(\mathbf{1 a})$ and $\left\{\mathrm{Fe}(4-\mathrm{CNpy})_{2}\left[\mathrm{Au}(\mathrm{CN})_{2}\right]_{2}\right\}-\left\{\mathrm{Fe}\left(\mathrm{H}_{2} \mathrm{O}\right)_{2}\left[\mathrm{Au}(\mathrm{CN})_{2}\right]_{2}\right\}$ (1b), present quite different supramolecular networks that show different magnetic behaviors. Compound 1a crystallizes in the centrosymmetric space group $\mathrm{Pbcn}$. The asymmetric unit contains two 4-CNpy, one type of $\mathrm{Fe}^{2+}$, and two types of crystallographically distinct $\left[\mathrm{Au}(\mathrm{CN})_{2}\right]^{-}$units which form Hofmann-like two dimensional layer structures with guest spaces. The layers are combined with another layer by strong gold-gold intermetalic interactions. Compound $\mathbf{1 b}$ crystallizes in the centrosymmetric space group Pnma. The bent bismonodentate $\left[\mathrm{Au}^{\mathrm{I}}(\mathrm{CN})_{2}\right]$ units and $\mathrm{Fe}^{\mathrm{II}}$ ions form a complicated interpenetrated three dimensional structure. In addition, $\mathbf{1 b}$ exhibits ferromagnetic interaction.
\end{abstract}

Keywords: coordination polymer; supramolecular isomerism; spin crossover; crystal engineering

\section{Introduction}

The designing of supramolecular networks is essential for practical spin crossover (SCO) materials [1-4]. The networks enhance the cooperativity in the entire crystal structure. Strong cooperativity leads to steep spin transition with a wide hysteresis loop [5,6]. From the viewpoint of constructing supramolecular networks, coordination polymers are useful material. However, systematic designing of networks is still hard because of the unexpected occurrence of supramolecular isomerism in the process of self-assembling. On the other hand, this structural diversity can result in unanticipated and interesting materials. Therefore, control of structural diversity represents fundamental research in crystal engineering. Since we reported the first Hofmann like two-dimensional (2-D) SCO coordination polymer $\left\{\mathrm{Fe}(\mathrm{py})_{2}\left[\mathrm{Ni}(\mathrm{CN})_{4}\right]\right\}_{n}$ (py = pyridine) [7], many 2-D layers of $\left\{\mathrm{Fe}^{\mathrm{II}}(\mathrm{L})_{2}\left[\mathrm{M}^{\mathrm{I}}(\mathrm{CN})_{2}\right]_{2}\right\}_{n}[8-16]\left(\mathrm{M}^{\mathrm{I}}=\mathrm{Ag}\right.$, or $\mathrm{Au}, \mathrm{L}=$ monodentate pyridine derivatives $)$ have been developed. These compounds show an almost similar bilayer structure because of their strongly determinate self-assembly process in which they link octahedral metal centers through the $\mathrm{N}$ atoms of the bidentate $\left[\mathrm{Au}(\mathrm{CN})_{2}\right]^{-}$unit with strong aurophilic interaction between layers. This structural constancy enables us to precisely modify its crystal structure and properties. However, the applicable 
ligands for this system are still determinative. For instance, 3-cyano pyridine (3-CNpy) displays three different polymorphs [8]. A strong polarity of cyano substituent must cause variations of the supramolecular networks, which strongly affects SCO properties. Therefore, more applicable ligands for this structural system must be investigated. Vice versa, cyano substituent offers new interesting networks and properties in cyano-bridged coordination polymers. Here, we report new supramolecular isomers of the general formula $\mathrm{Fe}(4-\mathrm{CNpy})_{2}\left[\mathrm{Au}(\mathrm{CN})_{2}\right]_{2} \cdot 1 / 2(4-\mathrm{CNpy})(\mathbf{1 a})$ and $\left\{\mathrm{Fe}(4-\mathrm{CNpy})_{2}\left[\mathrm{Au}(\mathrm{CN})_{2}\right]_{2}\right\}-\left\{\mathrm{Fe}\left(\mathrm{H}_{2} \mathrm{O}\right)_{2}\left[\mathrm{Au}(\mathrm{CN})_{2}\right]_{2}\right\}(\mathbf{1 b})$.

\section{Materials and Methods}

\subsection{Materials}

All the chemicals were purchased from commercial sources and used without any further purification.

\subsection{Synthesis}

\subsubsection{Preparation of Compound 1a}

$\mathrm{FeSO}_{4} \cdot\left(\mathrm{NH}_{4}\right)_{2} \mathrm{SO}_{4} \cdot 6 \mathrm{H}_{2} \mathrm{O}\left(0.0397 \mathrm{~g}, 1.01 \times 10^{-4} \mathrm{~mol}\right)$ ascorbic acid $\left(0.0208 \mathrm{~g}, 1.18 \times 10^{-4} \mathrm{~mol}\right)$ and $\mathrm{K}\left[\mathrm{Au}(\mathrm{CN})_{2}\right]\left(0.0582 \mathrm{~g}, 2.02 \times 10^{-4} \mathrm{~mol}\right)$ were dissolved in $2 \mathrm{~mL}$ of water. The other solution contained 4-CNpy $\left(0.0204 \mathrm{~g}, 1.96 \times 10^{-4} \mathrm{~mol}\right)$ in $5 \mathrm{~mL}$ water. The two solutions were mixed together. Yellow single crystals suitable for single crystal X-ray diffraction were formed over a day. The powder sample for superconducting quantum interference device (SQUID), X-ray powder diffraction (XRPD), thermos gravimetry/differential thermal analysis (TG/DTA) and elemental analysis was also prepared. One of these contained a mixture of $\mathrm{FeSO}_{4} \cdot\left(\mathrm{NH}_{4}\right)_{2} \mathrm{SO}_{4} \cdot 6 \mathrm{H}_{2} \mathrm{O}\left(0.0400 \mathrm{~g}, 1.02 \times 10^{-4} \mathrm{~mol}\right)$, ascorbic acid $\left(0.0204 \mathrm{~g}, 1.36 \times 10^{-4} \mathrm{~mol}\right)$ and $\mathrm{K}\left[\mathrm{Au}^{\mathrm{I}}(\mathrm{CN})_{2}\right]\left(0.0570 \mathrm{~g}, 1.98 \times 10^{-4} \mathrm{~mol}\right)$ in $1 \mathrm{~mL}$ water. The other contained a $1 \mathrm{~mL}$ ethanol-water (1:1) solution of 4-CNpy $\left(0.0206 \mathrm{~g}, 1.98 \times 10^{-4} \mathrm{~mol}\right)$. Yellow powder sample of 1a was formed immediately. The powder sample was checked by XRPD data (see Figure S1). Impurity and isomers were observed as almost absent. Elem. Anal. Calcd for $\mathrm{C}_{19} \mathrm{H}_{8} \mathrm{Au}_{2} \mathrm{FeN}_{9}$ : $\mathrm{C}, 28.03$; H, 1.24; N, 15.48. Found: C, 27.92; H, 1.38; N, 15.35. IR( $\left.\mathrm{cm}^{-1}\right)$ : 2237 ( $\left.v \mathrm{CN}(4-\mathrm{CNpy})\right), 2157,2169(v \mathrm{CN})$.

\subsubsection{Preparation of Compound $\mathbf{1 b}$}

Complex $1 \mathbf{b}$ was prepared by the same procedure as $1 \mathbf{a}$. The reaction mixture was allowed to stand undisturbed for 2 days. After forming yellow single crystals (1a), orange crystals (1b) slowly grew. The crystalline sample for SQUID measurement was picked up using a binocular lens. The samples were checked by XRPD data (Figure S1). Impurity of the samples was observed as almost absent. Due to the small amount of sample picked, the background of the diffraction data were very high. Elem. Anal. Calcd for $\mathrm{C}_{20} \mathrm{H}_{11} \mathrm{Au}_{4} \mathrm{Fe}_{2} \mathrm{~N}_{12} \mathrm{O}_{2}: \mathrm{C}, 17.77 ; \mathrm{H}, 0.89 ; \mathrm{N}, 12.43$. Found: $\mathrm{C}, 17.75 ; \mathrm{H}, 1.13 ; \mathrm{N}$, 12.15. IR $\left(\mathrm{cm}^{-1}\right): 2250(v \mathrm{CN}(4-\mathrm{CNpy})), 2169(v \mathrm{CN})$

\subsection{X-ray Crystallography}

Data collection was performed on a BRUKER APEX SMART CCD area-detector diffractometer for $\mathbf{1} \mathbf{a}$ and $\mathbf{1 b}$ with Monochrometed Mo-K $\alpha$ radiation $(\lambda=0.71073 \AA$ ) (Bruker, Billerica, MA, USA). A selected single crystal was carefully mounted on a thin glass capillary and immediately placed under liquid $\mathrm{N}_{2}$ cooled $\mathrm{N}_{2}$ stream in each case. The diffraction data were treated using SMART and SAINT, and absorption correction was performed using SADABS [17]. The structures were solved by using direct methods with SHELXTL [18]. All non-hydrogen atoms were refined anisotropically, and the hydrogen atoms were generated geometrically. Pertinent crystallographic parameters and selected metric parameters for $\mathbf{1 a}$ and $\mathbf{1 b}$ are displayed in Tables 1-3. Diffraction data of $\mathbf{1 a}$ in high spin (HS) state was measured at $150 \mathrm{~K}$ in order to suppress the thermal motion of the guest molecules. When the sample was sufficiently cooled, both compounds showed a drastic and reversible change of color from yellow (1a) or orange (1) to purple. The crystal structure of $\mathbf{1 a}$ in low spin 
(LS) state could not be determined. The low-quality data at $90 \mathrm{~K}$ was likely due to the occurrence of a sharp phase transition that provoked a notable increase of the mosaicity of the whole crystal structure. We described here the only HS state at $150 \mathrm{~K}$. Crystallographic data have been deposited with Cambridge Crystallographic Data Centre: Deposition numbers CCDC-1869343 for compound 1a (150 K), CCDC-1869342 for $\mathbf{1 b}$ (298 K), and CCDC-1869341 for $\mathbf{1 b}$ (90 K). These data can be obtained free of charge via http:/ / www.ccdc.cam.ac.uk/conts/retrieving.html.

\subsection{Magnetic Measurements}

Measurements of the temperature dependence of the magnetic susceptibility of the complexes 1a and $\mathbf{1 b}$ of the powdered samples in the temperature range 2-300 $\mathrm{K}$ with a cooling and heating rate of $2 \mathrm{~K} \cdot \mathrm{min}^{-1}$ in a $1 \mathrm{kOe}$ field were measured on a MPMS-XL Quantum Design SQUID magnetometer. The diamagnetism of the samples and sample holders were taken into account.

Table 1. Crystal data and structure refinement for compounds $\mathbf{1 a}$ and $\mathbf{1 b}$.

\begin{tabular}{cccc}
\hline & $\mathbf{1 a}(\mathbf{1 5 0} \mathbf{K})$ & $\mathbf{1 b} \mathbf{( 2 9 8 ~ \mathbf { ~ } )}$ & $\mathbf{1 b} \mathbf{( 9 0 ~ \mathbf { ~ } )}$ \\
\hline Empirical formula & $\mathrm{C}_{19} \mathrm{H}_{8} \mathrm{Au}_{2} \mathrm{FeN}_{9}$ & $\mathrm{C}_{20} \mathrm{H}_{11} \mathrm{Au}_{4} \mathrm{Fe}_{2} \mathrm{~N}_{12} \mathrm{O}_{2}$ & $\mathrm{C}_{20} \mathrm{H}_{11} \mathrm{Au}_{4} \mathrm{Fe}_{2} \mathrm{~N}_{12} \mathrm{O}_{2}$ \\
Formula weight & 812.13 & 1350.97 & 1350.97 \\
Crystal size $/ \mathrm{mm}^{3}$ & $0.55 \times 0.28 \times 0.22$ & $0.15 \times 0.13 \times 0.05$ & $0.38 \times 0.15 \times 0.05$ \\
Crystal system & Orthorhombic & Orthorhombic & Orthorhombic \\
$a / \AA$ & $21.658(2)$ & $7.6273(7)$ & $7.6243(4)$ \\
$b / \AA$ & $13.7647(15)$ & $30.007(3)$ & $29.1960(16)$ \\
$c / \AA$ & $15.5895(17)$ & $13.7694(13)$ & $13.5000(7)$ \\
$V / \AA$ & $4647.4(9)$ & $3151.5(5)$ & $3005.1(3)$ \\
Space group & $P b c n$ & $P n m a$ & $P n m a$ \\
$Z$ value & 8 & 4 & 4 \\
$D_{\text {calc }}$ & 2.321 & 2.847 & 2.986 \\
$F(000)$ & 2952 & 2396 & 2396 \\
No. of reflections & 28,466 & 19,996 & 20,977 \\
No. of observations & 5443 & 3976 & 3808 \\
Parameters & 284 & 196 & 186 \\
Temperature/K & $150(2)$ & 298 & 90 \\
Final $R_{1}, R_{\mathrm{w}}(I>2 s)$ & $0.0411,0.1043$ & $0.0474,0.1168$ & $0.0396,0.1048$ \\
Final $R_{1}, R_{\mathrm{W}}$ (all data) & $0.0715,0.1197$ & $0.0730,0.1346$ & $0.0439,0.1212$ \\
Goodness-of-fit & 1.050 & 0.965 & 1.413 \\
\hline
\end{tabular}

Table 2. Selected bond lengths and angles for 1a.

\begin{tabular}{ccc}
\hline Bond Lengths (Å) for 1a (150 K) & \multicolumn{2}{c}{ Bond Angles $\left(^{\circ}\right.$ ) for 1a (150 K) } \\
\hline $\mathrm{Fe}(1)-\mathrm{N}(1): 2.234(9)$ & $\mathrm{N}(1)-\mathrm{Fe}(1)-\mathrm{N}(3): 175.9(3)$ & $\mathrm{N}(5)-\mathrm{Fe}(1)-\mathrm{N}(8): 90.0(3)$ \\
$\mathrm{Fe}(1)-\mathrm{N}(3): 2.227(8)$ & $\mathrm{N}(1)-\mathrm{Fe}(1)-\mathrm{N}(5): 93.0(3)$ & $\mathrm{N}(6)-\mathrm{Fe}(1)-\mathrm{N}(7): 88.2(3)$ \\
$\mathrm{Fe}(1)-\mathrm{N}(5): 2.161(8)$ & $\mathrm{N}(1)-\mathrm{Fe}(1)-\mathrm{N}(6): 94.5(3)$ & $\mathrm{N}(6)-\mathrm{Fe}(1)-\mathrm{N}(8): 176.4(3)$ \\
$\mathrm{Fe}(1)-\mathrm{N}(6): 2.129(8)$ & $\mathrm{N}(1)-\mathrm{Fe}(1)-\mathrm{N}(7): 89.4(3)$ & $\mathrm{N}(7)-\mathrm{Fe}(1)-\mathrm{N}(8): 95.1(3)$ \\
$\mathrm{Fe}(1)-\mathrm{N}(7): 2.121(8)$ & $\mathrm{N}(1)-\mathrm{Fe}(1)-\mathrm{N}(8): 84.0(3)$ & $\mathrm{C}(13)-\mathrm{N}(5)-\mathrm{Fe}(1): 167.4(8)$ \\
$\mathrm{Fe}(1)-\mathrm{N}(8): 2.146(8)$ & $\mathrm{N}(3)-\mathrm{Fe}(1)-\mathrm{N}(5): 86.9(3)$ & $\mathrm{C}(14)-\mathrm{N}(6)-\mathrm{Fe}(1): 162.4(8)$ \\
$\mathrm{Au}(1)-\mathrm{C}(13): 1.999(9)$ & $\mathrm{N}(3)-\mathrm{Fe}(1)-\mathrm{N}(6): 89.6(3)$ & $\mathrm{C}(15)-\mathrm{N}(7)-\mathrm{Fe}(1): 163.2(8)$ \\
$\mathrm{Au}(1)-\mathrm{C}(16): 1.990(9)$ & $\mathrm{N}(3)-\mathrm{Fe}(1)-\mathrm{N}(7): 91.1(3)$ & $\mathrm{C}(16)-\mathrm{N}(8)-\mathrm{Fe}(1): 161.3(9)$ \\
$\mathrm{Au}(2)-\mathrm{C}(14): 1.986(9)$ & $\mathrm{N}(3)-\mathrm{Fe}(1)-\mathrm{N}(8): 91.9(3)$ & $\mathrm{C}(13)-\mathrm{Au}(1)-\mathrm{C}(16): 178.0(4)$ \\
$\mathrm{Au}(2)-\mathrm{C}(15): 1.981(10)$ & $\mathrm{N}(5)-\mathrm{Fe}(1)-\mathrm{N}(6): 86.8(3)$ & $\mathrm{C}(14)-\mathrm{Au}(2)-\mathrm{C}(15): 176.8(4)$ \\
& $\mathrm{N}(5)-\mathrm{Fe}(1)-\mathrm{N}(7): 174.6(3)$ \\
\end{tabular}

\section{Results and Discussion}

\subsection{Crystal Structures}

\subsubsection{Crystal Structure of Compound 1a $(\mathrm{T}=298 \mathrm{~K})$}

The crystal structure of $\mathbf{1 a}$ at $298 \mathrm{~K}$ crystallized in the orthorhombic centrosymmetric space group $\mathrm{Pbcn}$. The asymmetric unit of the complex consisted of the $\mathrm{Fe}(\text { ligand })_{2}\left[\mathrm{Au}(\mathrm{CN})_{2}\right]_{2}$ formula with a guest molecule (Figure 1a). This complex had one type of independent $\mathrm{Fe}^{\mathrm{II}}$ ion octahedrally coordinated 
by six $\mathrm{N}$ atoms. The axial $\mathrm{Fe}(1)-\mathrm{N}_{\text {py }}$ bond lengths $(\mathrm{Fe}(1)-\mathrm{N}(1)=2.234(9) \AA, \mathrm{Fe}(1)-\mathrm{N}(3)=2.227(8) \AA)$ and $\mathrm{Fe}(1)-\mathrm{N}_{\mathrm{CN}}$ bond lengths $(\mathrm{Fe}(1)-\mathrm{N}(5)=2.161(8) \AA, \mathrm{Fe}(1)-\mathrm{N}(6)=2.129(8) \AA, \mathrm{Fe}(1)-\mathrm{N}(7)=2.121(8) \AA$, $\mathrm{Fe}(1)-\mathrm{N}(8)=2.146(8) \AA$ ) were almost identical to that of $\mathbf{1 b}$. The equatorial positions were occupied by two quasilinear $\left[\mathrm{Au}^{\mathrm{I}}(\mathrm{CN})_{2}\right]^{-}$, which comprised a 2-D layer structure defined by square-shaped $\left[\mathrm{Fe}^{\mathrm{II}} \mathrm{Au}^{\mathrm{I}}(\mathrm{CN})_{2}\right]_{4}$ windows (Figure $1 \mathrm{~b}$ ). The layers interacted via pairs of defining bilayers (Figure $1 \mathrm{c}, \mathrm{d}$ ),

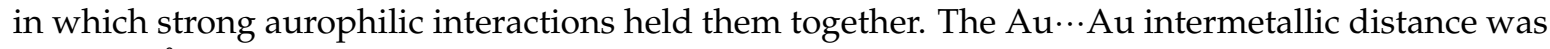
3.1134(6) ^ which was much shorter than that of $\mathbf{1 b}$. Although the former reported bilayer structures had no guest spaces, the interlayer space of 1a formed one dimensional (1-D) channels parallel to the $\mathrm{c}$ axis, which were occupied by uncoordinated 4-CNpy. The guest molecules were disordered at two positions. The reason for enough space to include guest molecules was the steric effect from the 4-position substituent bulk. As shown in Figure 1c, the four position substituent was almost vertical to the layer. Thus, it would cause the pressure on the layer resulting in expanded interlayer space.

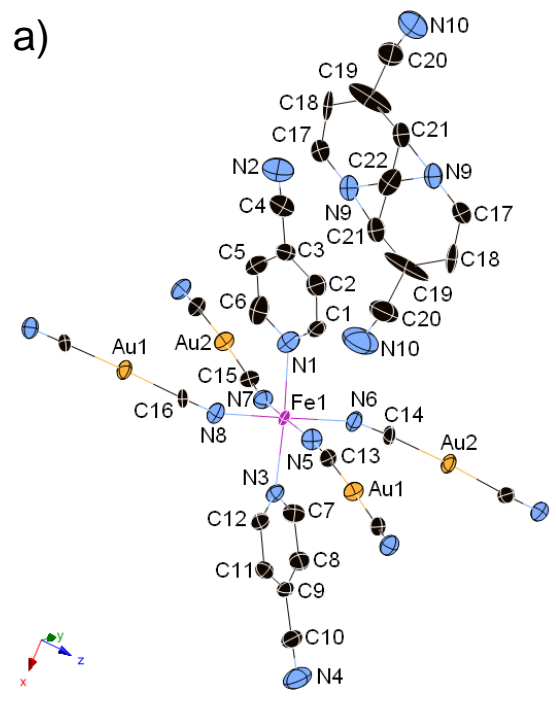

c)

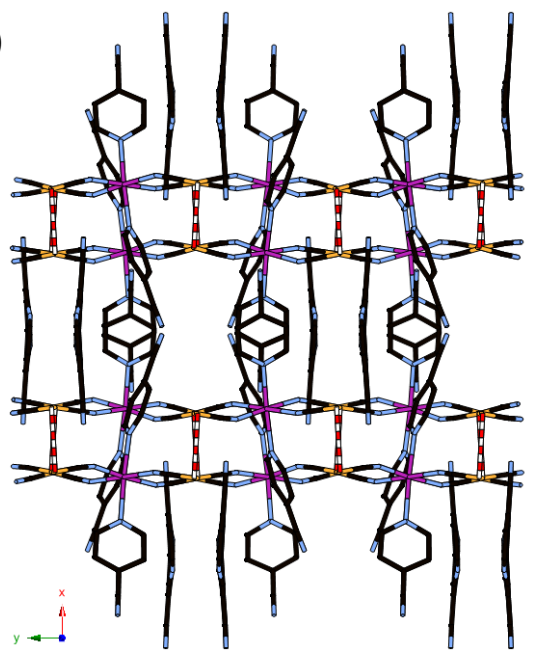

b)

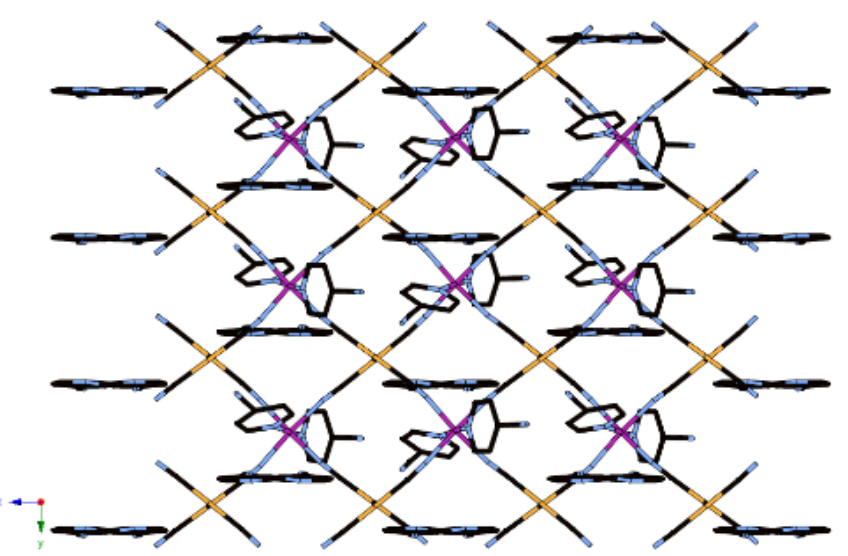

d)

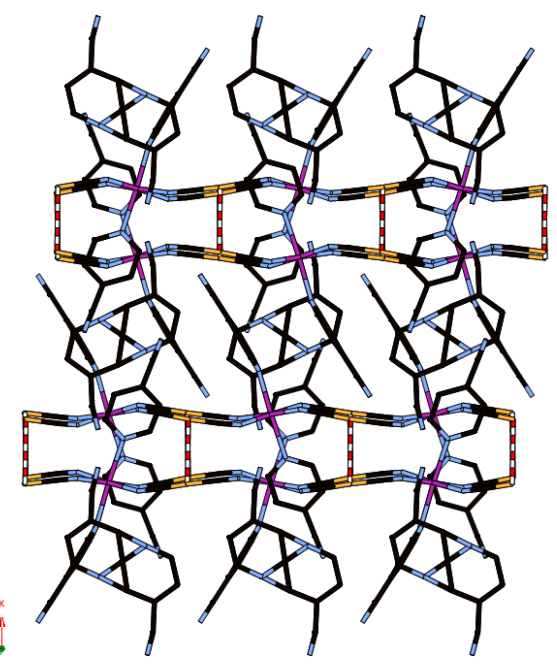

Figure 1. (a) Coordination structure of $1 \mathrm{a}$ containing its asymmetric unit at $150 \mathrm{~K} ;(\mathbf{b})$ view of the bilayer

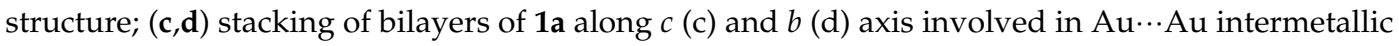
interactions as indicated by red and white lines. In these pictures, hydrogen atoms are omitted for clarity.

The closely related Hofmann-like 2-D clathrate compound, $\left\{\mathrm{Fe}\left[4-(3-\text { pentyl)pyridine }]_{2}\left[\mathrm{Au} \mathrm{u}^{\mathrm{I}}(\mathrm{CN})_{2}\right]_{2}\right.\right.$. (guest) $\}_{n}$ (guest $=4$-(3-pentyl)pyridine), had been reported [19]. This compound formed a flat 
monolayer structure. 4-(3-pentyl) substituent was apparently of lager bulk than that of the 4-CN substituent. This much larger bulk caused bilayer interaction to break.

\subsubsection{Crystal Structure of Compound $\mathbf{1 b}(\mathrm{T}=298 \mathrm{~K})$}

Compound $\mathbf{1 b}$ at $298 \mathrm{~K}$ crystallized in the orthorhombic centrosymmetric space group Pnma. The asymmetric unit also consisted of the cyano bridged hetero-metal coordination (Figure 2a). There were two crystallographically different octahedral $\mathrm{Fe}^{\mathrm{II}}$ ions. $\mathrm{Fe}(1)$ was coordinated by six $\mathrm{N}$ atoms of two 4-CNpy ligands and four $\mathrm{CN}$ substituents from $\left[\mathrm{Au}^{\mathrm{I}}(\mathrm{CN})_{2}\right]^{-}$units, which was similar to that of 1a. The axial $\mathrm{Fe}(1)-\mathrm{N}_{\text {py }}$ bond lengths $(\mathrm{Fe}(1)-\mathrm{N}(1)=2.226(7) \AA)$ were apparently longer than the $\mathrm{Fe}(1)-\mathrm{N}_{\mathrm{CN}}$ bond lengths $(\mathrm{Fe}(1)-\mathrm{N}(3)=2.157(7) \AA, \mathrm{Fe}(1)-\mathrm{N}(4)=2.144(7) \AA)$. On the other hand, the axial $\mathrm{Fe}(2)-\mathrm{O}$ bond lengths $(\mathrm{Fe}(2)-\mathrm{O}(1)=2.078(13) \AA, \mathrm{Fe}(2)-\mathrm{O}(2)=2.158(9) \AA)$ were close to the $\mathrm{Fe}(2)-\mathrm{N}_{\mathrm{CN}}$ bond lengths $(\mathrm{Fe}(2)-\mathrm{N}(5)=2.130(8) \AA, \mathrm{Fe}(2)-\mathrm{N}(6)=2.187(8) \AA)$. It is important to note that hydrogen bonds existed between $\mathrm{N}(2)$ of cyano group in $4-\mathrm{CNpy}$ and $\mathrm{O}(1)(\mathrm{N}(2) \cdots \mathrm{O}(1)=2.905(15) \AA)$. Due to the different coordination environment, the apical axis of Fe(1) was not parallel to the apical axis of $\mathrm{Fe}(2)$. Furthermore, the coordination geometry of the Fe(1) site was almost octahedron; the bond angle of the apical axis was $180(4)^{\circ}$. On the other hand, the $\mathrm{Fe}(2)$ site showed a quite distorted octahedron $\left(\mathrm{O}(1)-\mathrm{Fe}(2)-\mathrm{O}(2)=169.5(6)^{\circ}\right.$ and $\left.\mathrm{N}(5)-\mathrm{Fe}(2)-\mathrm{N}(6)=172.3(3)^{\circ}\right)$. Consequently, the bent bismonodentate $\left[\mathrm{Au}^{\mathrm{I}}(\mathrm{CN})_{2}\right]$ units and $\mathrm{Fe}^{\mathrm{II}}$ ions formed bent rectangular $\left[\mathrm{Fe}^{\mathrm{II}} \mathrm{Au}^{\mathrm{I}}(\mathrm{CN})_{2}\right]_{4}$ mesh network topology (Figure $2 b$ ). The rectangular moieties were penetrated by the other frameworks, which gave rise to a triply interpenetrated structure (Figure 2c). In addition, the closest approach between $\mathrm{Au} \cdots \mathrm{Au}$ suggested the presence of aurophilic interactions $(\mathrm{Au}(1) \cdots \mathrm{Au}(2)=3.3705(5) \AA$ and 3.3876(5) $\AA$ ) which linked the other frameworks (Figure 2c,d). In previous works, isostructural compound $\left\{\mathrm{Mn}(4-\mathrm{CNpy})_{2}\left[\mathrm{Ag}(\mathrm{CN})_{2}\right]_{2}\right\}-\left\{\mathrm{Mn}\left(\mathrm{H}_{2} \mathrm{O}\right)_{2}\left[\mathrm{Ag}(\mathrm{CN})_{2}\right]_{2}\right\}\left(\mathbf{1 b}^{\prime}\right)$ had been reported [20]. This compound also showed similar hydrogen bonding and intermetallic Ag $\cdots$ Ag interactions.
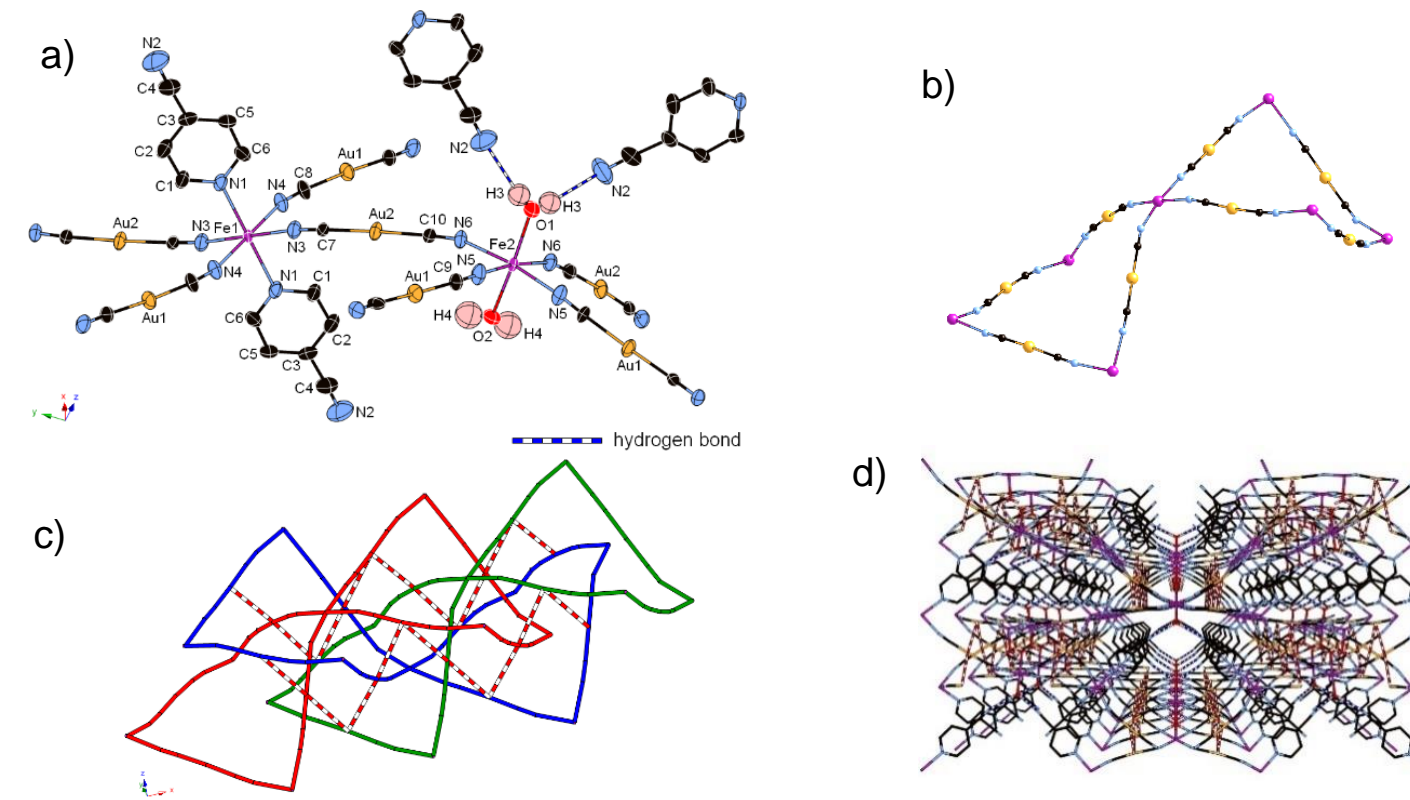

d)

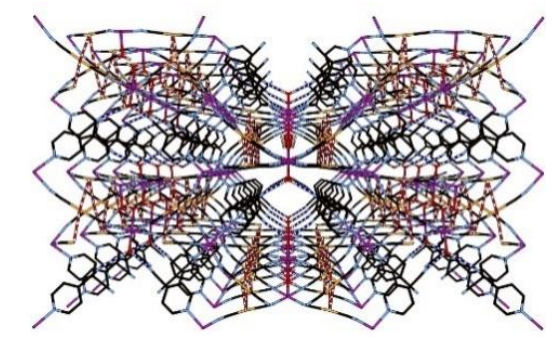

Figure 2. (a) Coordination structure of $\mathbf{1 b}$ containing its asymmetric unit at $298 \mathrm{~K}$ involved in hydrogen bonding interactions as indicated by blue and white lines; $(\mathbf{b})$ bent rectangular $\left[\mathrm{Fe}^{\mathrm{II}} \mathrm{Au}^{\mathrm{I}}(\mathrm{CN})_{2}\right]_{4}$ mesh structure; (c) cylinder drawing of triply interpenetrated 3D-networks of $\mathbf{1 b}$ involved in hydrogen bonding interactions as indicated by red and white lines; (d) perspective view of the crystal structure along $a$ axis. In these pictures, hydrogen atoms are omitted for clarity. 


\subsubsection{Structure of Compound $\mathbf{1 b}(\mathrm{T}=90 \mathrm{~K})$}

The crystal structure of $\mathbf{1 b}$ at $90 \mathrm{~K}$ was almost identical to that observed at $298 \mathrm{~K}$. The $\mathrm{Fe}(1)-\mathrm{N}_{\mathrm{py}}$ bond lengths $(\mathrm{Fe}(1)-\mathrm{N}(1)=1.998(7) \AA)$ and $\mathrm{Fe}(1)-\mathrm{N}_{\mathrm{CN}}$ bond lengths $(\mathrm{Fe}(1)-\mathrm{N}(3)=1.937(7) \AA, \mathrm{Fe}(1)-\mathrm{N}(4)$ $=1.941(7) \AA)$ corresponded quite well to those expected for LS state. On the other hand Fe(2)-O bond lengths $(\mathrm{Fe}(2)-\mathrm{O}(1)=2.095(9) \AA, \mathrm{Fe}(2)-\mathrm{O}(2)=2.112(9) \AA)$ and $\mathrm{Fe}(2)-\mathrm{N}_{\mathrm{CN}}$ bond lengths $(\mathrm{Fe}(2)-\mathrm{N}(5)=$ 2.132(7) $\AA, \mathrm{Fe}(2)-\mathrm{N}(6)=2.190(8) \AA$ ) were almost identical to that of $298 \mathrm{~K}$. Hydrogen bonding and intermetallic interactions were slightly shorter than that of the HS state $(\mathrm{Au}(1) \cdots \mathrm{Au}(2)=3.3462(4) \AA$, $3.3745(4) \AA$ and $\mathrm{N}(2) \cdots \mathrm{O}(1)=2.862(11) \AA$ ). The shortest $\mathrm{Fe} \cdots \mathrm{Fe}$ separation was 5.811(2) $\mathrm{A}$ between $\mathrm{Fe}(2)$ centers which was bridged by the aurophilic interactions (see Figure S3). This was much shorter than that of the other Fe $\cdots$ Fe separation $(\mathrm{Fe}(1) \cdots \mathrm{Fe}(1)=13.280(1) \AA, \mathrm{Fe}(1) \cdots \mathrm{Fe}(2)=9.746(1) \AA)$.

Table 3. Selected bond lengths and angles for $\mathbf{1 b}$.

\begin{tabular}{|c|c|c|}
\hline Bond Lengths ( $\AA$ ) for $1 \mathrm{~b}(298 \mathrm{~K})$ & \multicolumn{2}{|c|}{ Bond Angles $\left({ }^{\circ}\right)$ for $1 \mathrm{~b}(298 \mathrm{~K})$} \\
\hline $\mathrm{Fe}(1)-\mathrm{N}(1): 2.226(7)$ & $\mathrm{N}(1)-\mathrm{Fe}(1)-\mathrm{N}(1): 180.0(3)$ & $\mathrm{O}(1)-\mathrm{Fe}(2)-\mathrm{O}(2): 169.5(6)$ \\
\hline $\mathrm{Fe}(1)-\mathrm{N}(3): 2.157(7)$ & $\mathrm{N}(1)-\mathrm{Fe}(1)-\mathrm{N}(3): 90.0(3)$ & $\mathrm{O}(1)-\mathrm{Fe}(2)-\mathrm{N}(5): 96.6(4)$ \\
\hline $\mathrm{Fe}(1)-\mathrm{N}(4): 2.144(7)$ & $\mathrm{N}(1)-\mathrm{Fe}(1)-\mathrm{N}(4): 89.5(3)$ & $\mathrm{O}(1)-\mathrm{Fe}(2)-\mathrm{N}(6): 89.9(3)$ \\
\hline $\mathrm{Fe}(2)-\mathrm{O}(1): 2.078(13)$ & $\mathrm{N}(3)-\mathrm{Fe}(1)-\mathrm{N}(3): 180.0(3)$ & $\mathrm{O}(2)-\mathrm{Fe}(2)-\mathrm{N}(5): 90.8(4)$ \\
\hline $\mathrm{Fe}(2)-\mathrm{O}(2): 2.158(9)$ & $\mathrm{N}(3)-\mathrm{Fe}(1)-\mathrm{N}(4): 91.3(3)$ & $\mathrm{O}(2)-\mathrm{Fe}(2)-\mathrm{N}(6): 83.3(3)$ \\
\hline $\mathrm{Fe}(2)-\mathrm{N}(5): 2.130(8)$ & $\mathrm{N}(4)-\mathrm{Fe}(1)-\mathrm{N}(4): 180.0(4)$ & $\mathrm{N}(5)-\mathrm{Fe}(2)-\mathrm{N}(5): 89.5(5)$ \\
\hline $\mathrm{Fe}(2)-\mathrm{N}(6): 2.187(8)$ & $\mathrm{C}(7)-\mathrm{N}(3)-\mathrm{Fe}(1): 167.1(8)$ & $\mathrm{N}(5)-\mathrm{Fe}(2)-\mathrm{N}(6): 85.6(3)$ \\
\hline $\mathrm{Au}(1)-\mathrm{C}(8): 1.985(9)$ & $\mathrm{C}(8)-\mathrm{N}(4)-\mathrm{Fe}(1): 166.6(8)$ & $\mathrm{N}(6)-\mathrm{Fe}(2)-\mathrm{N}(6): 98.7(4)$ \\
\hline $\mathrm{Au}(1)-\mathrm{C}(9): 1.978(9)$ & $\mathrm{C}(8)-\mathrm{Au}(1)-\mathrm{C}(9): 175.9(4)$ & $\mathrm{N}(5)-\mathrm{Fe}(2)-\mathrm{N}(6): 172.3(3)$ \\
\hline $\mathrm{Au}(2)-\mathrm{C}(7): 1.992(9)$ & $\mathrm{C}(7)-\mathrm{Au}(2)-\mathrm{C}(10): 176.6(3)$ & $\mathrm{C}(9)-\mathrm{N}(5)-\mathrm{Fe}(2): 169.6(8)$ \\
\hline $\mathrm{Au}(2)-\mathrm{C}(10): 1.992(9)$ & & $\mathrm{C}(10)-\mathrm{N}(6)-\mathrm{Fe}(2): 162.0(8)$ \\
\hline Bond Lengths (Å) for $1 \mathrm{~b}(90 \mathrm{~K})$ & \multicolumn{2}{|c|}{ Bond Angles $\left({ }^{\circ}\right)$ for $1 \mathrm{~b}(90 \mathrm{~K})$} \\
\hline $\mathrm{Fe}(1)-\mathrm{N}(1): 1.998(7)$ & $\mathrm{N}(1)-\mathrm{Fe}(1)-\mathrm{N}(1): 180.0(4)$ & $\mathrm{O}(1)-\mathrm{Fe}(2)-\mathrm{O}(2): 169.1(4)$ \\
\hline $\mathrm{Fe}(1)-\mathrm{N}(3): 1.937(7)$ & $\mathrm{N}(1)-\mathrm{Fe}(1)-\mathrm{N}(3): 90.5(3)$ & $\mathrm{O}(1)-\mathrm{Fe}(2)-\mathrm{N}(5): 96.2(3)$ \\
\hline $\mathrm{Fe}(1)-\mathrm{N}(4): 1.941(7)$ & $\mathrm{N}(1)-\mathrm{Fe}(1)-\mathrm{N}(4): 90.4(3)$ & $\mathrm{O}(1)-\mathrm{Fe}(2)-\mathrm{N}(6): 89.3(3)$ \\
\hline $\mathrm{Fe}(2)-\mathrm{O}(1): 2.095(9)$ & $\mathrm{N}(3)-\mathrm{Fe}(1)-\mathrm{N}(3): 180.0(2)$ & $\mathrm{O}(2)-\mathrm{Fe}(2)-\mathrm{N}(5): 91.5(3)$ \\
\hline $\mathrm{Fe}(2)-\mathrm{O}(2): 2.112(9)$ & $\mathrm{N}(3)-\mathrm{Fe}(1)-\mathrm{N}(4): 90.3(3)$ & $\mathrm{O}(2)-\mathrm{Fe}(2)-\mathrm{N}(6): 83.6(3)$ \\
\hline $\mathrm{Fe}(2)-\mathrm{N}(5): 2.132(7)$ & $\mathrm{N}(4)-\mathrm{Fe}(1)-\mathrm{N}(4): 180.0(4)$ & $\mathrm{N}(5)-\mathrm{Fe}(2)-\mathrm{N}(5): 90.6(4)$ \\
\hline $\mathrm{Fe}(2)-\mathrm{N}(6): 2.190(8)$ & $\mathrm{C}(7)-\mathrm{N}(3)-\mathrm{Fe}(1): 170.7(7)$ & $\mathrm{N}(5)-\mathrm{Fe}(2)-\mathrm{N}(6): 85.0(3)$ \\
\hline $\mathrm{Au}(1)-\mathrm{C}(8): 1.985(9)$ & $\mathrm{C}(8)-\mathrm{N}(4)-\mathrm{Fe}(1): 172.3(7)$ & $\mathrm{N}(6)-\mathrm{Fe}(2)-\mathrm{N}(6): 98.9(4)$ \\
\hline $\mathrm{Au}(1)-\mathrm{C}(9): 1.977(9)$ & $\mathrm{C}(8)-\mathrm{Au}(1)-\mathrm{C}(9): 174.8(3)$ & $\mathrm{N}(5)-\mathrm{Fe}(2)-\mathrm{N}(6): 173.4(3)$ \\
\hline $\mathrm{Au}(2)-\mathrm{C}(7): 1.983(9)$ & $\mathrm{C}(7)-\mathrm{Au}(2)-\mathrm{C}(10): 174.2(3)$ & $\mathrm{C}(9)-\mathrm{N}(5)-\mathrm{Fe}(2): 168.6(7)$ \\
\hline $\mathrm{Au}(2)-\mathrm{C}(10): 1.989(8)$ & & $\mathrm{C}(10)-\mathrm{N}(6)-\mathrm{Fe}(2): 161.7(7)$ \\
\hline
\end{tabular}

\subsection{Thermal Analysis}

The thermal analysis of 1a showed the three step weight loss between $380 \mathrm{~K}$ and $580 \mathrm{~K}$ corresponded to the loss of the two coordinated molecules of 4-CNpy and 0.5 solvent molecules (observed loss: $18.0 \%$ (first step) $=$ ca. 1.5 molecules, $6.4 \%$ (second step) $=$ ca. 0.5 molecule, $6.7 \%$ (third step) $=$ ca. 0.5 molecule) (Figure S2). This result was consistent with the elemental analysis.

\subsection{Magnetic Properties}

\subsubsection{Thermal Dependence Magnetic Behavior of Compound 1a}

Figure 3a shows the thermal dependence of $\chi_{M} T$ for $1 a$ with $\chi_{M}$ being the molar magnetic susceptibility and $\mathrm{T}$ the temperature. At room temperature, $\chi_{\mathrm{M}}^{\mathrm{T}}$ was $4.21 \mathrm{~m}^{3} \cdot \mathrm{K}^{\mathrm{mol}} \mathrm{mol}^{-1}$. Upon cooling, $\chi_{M} T$ remained almost constant down to $120 \mathrm{~K}$; below this temperature, $\chi_{M} T$ underwent a sharp decrease to around $50 \%$ conversion with approximately $1 \mathrm{~K}$ hysteresis loop $\left(\mathrm{T}_{\mathrm{C}}{ }^{\text {down }}=111 \mathrm{~K}\right.$, $\mathrm{T}_{\mathrm{c}}$ up $=112 \mathrm{~K}$ ). The decrease in the value of $\chi_{\mathrm{M}} \mathrm{T}$ at lower temperature was due to the typical behavior of zero-field splitting (ZFS). 

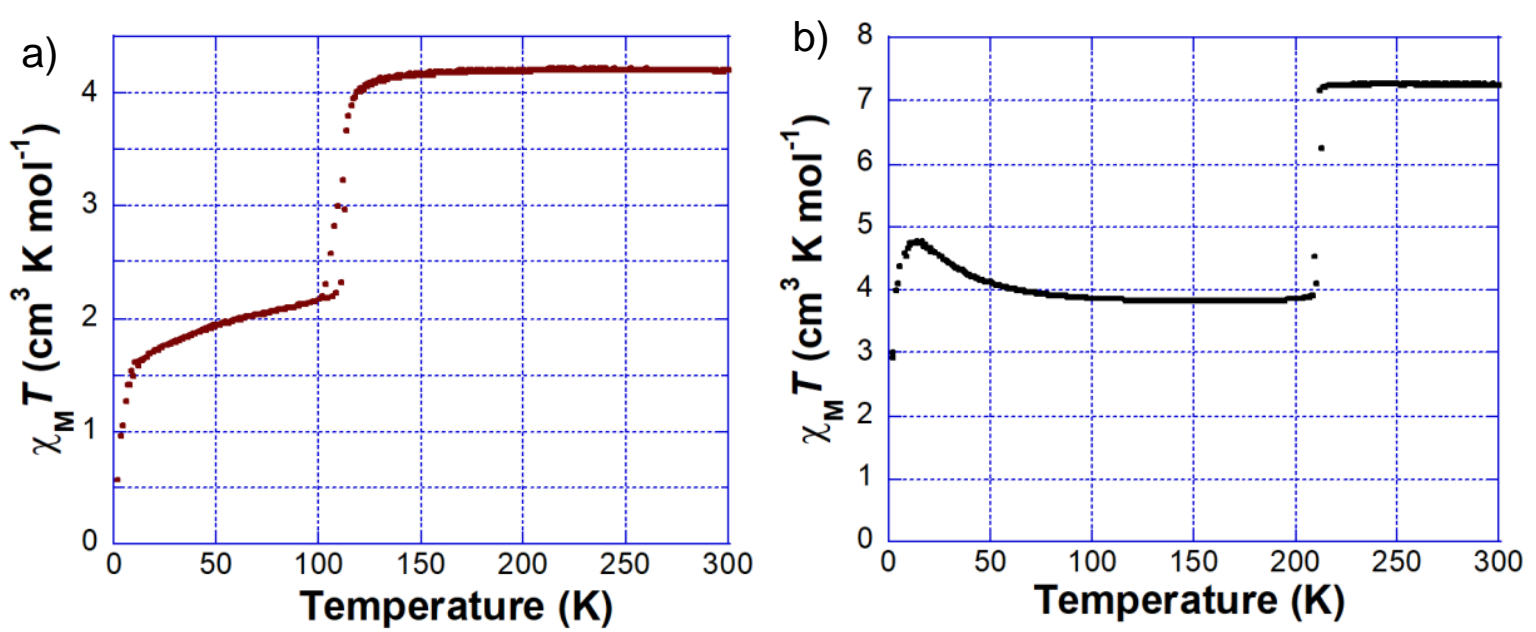

Figure 3. (a) Thermal dependence of $\chi_{\mathrm{M}}^{T}$ plot for $\mathbf{1 a} ;(\mathbf{b})$ thermal dependence of $\chi_{\mathrm{M}}{ }^{T}$ plot for $\mathbf{1} \mathbf{b}$.

\subsubsection{Thermal Dependence Magnetic Behavior of Compound $\mathbf{1 b}$}

$\chi_{M} T$ versus $T$ plotted for $\mathbf{1 b}$ are shown in Figure $3 b$. At room temperature, the $\chi_{M} T$ value was 7.25 which indicated the characteristic of two Fe(II) ions in HS state. The value was slightly higher than that of a pure spin only system, whereas the value was similar to the values of other Hofmann-like $\mathrm{SCO} F e(\mathrm{II})$ compounds. The $\chi_{\mathrm{M}} T$ value was constant in the range $215-300 \mathrm{~K}$. Below this temperature range, it displayed almost $50 \%$ abrupt spin transition $\left(T_{\mathrm{C}}=211 \mathrm{~K}\right)$. This half spin transition behavior agreed quite well with the different $\mathrm{Fe}-\mathrm{N}$ bond lengths between $\mathrm{Fe}(1)$ and $\mathrm{Fe}(2)$ species at $90 \mathrm{~K}$. Thus only $\mathrm{Fe}(1)$ species change the spin state. On the other hand, $\left[\mathrm{Fe}(2) \mathrm{N}_{4} \mathrm{O}_{2}\right]$ coordination environment must maintain the HS state at the full temperature range. After the transition, it then increased to a maximum of $4.77 \mathrm{~cm}^{3} \cdot \mathrm{K} \cdot \mathrm{mol}^{-1}$ at around $20 \mathrm{~K}$, indicative of a ferromagnetic interaction between the $\mathrm{Fe}(\mathrm{II})$ centers. On the other hand, the isostructural former reported that compound $\mathbf{1} \mathbf{b}^{\mathbf{\prime}}$ showed weak antiferromagnetic interaction between two $\mathrm{Mn}^{\mathrm{II}}$ (HS state, $\mathrm{S}=5 / 2$ ). Although in a similar coordination environment, $\mathbf{1 b}$ showed ferromagnetic interaction. In terms of the spin state, the X-ray structural analysis of $\mathbf{1 b}$ at $90 \mathrm{~K}$ gave evidence of the arrangement of a $\cdots \mathrm{Fe}(\mathrm{HS})-\mathrm{Fe}(\mathrm{LS}) \cdots$ pair. On the other hand, $\mathbf{1 b}$ showed the different arrangement of $\cdots \mathrm{Mn}(\mathrm{HS})-\mathrm{Mn}(\mathrm{HS}) \cdots$. Thus, $\mathbf{1 b}$ apparently much further distorted structure. Consequently, the magnetic structure of the residual HS site of $\mathrm{Fe}(2)$ could cause the different magnetic coupling. In fact $\mathrm{Fe}(2)$ ions of $\mathrm{HS}$ site were close to each other in the supramolecular networks. At even lower temperature, the decrease in the value of $\chi_{M} T$ was similar to 1a due to ZFS effects.

\section{Conclusions}

The new supramolecular networks designed by the components of Hofmann-like frameworks with 4-CNpyridine were reported. These compounds showed unique multi-dimensional supramolecular networks involving hydrogen interactions and strong metallophilic interactions. Specifically, $\mathbf{1 b}$ exhibited the two magnetic functions of a SCO and a ferromagnetic transition. The diversity of the self-assembly process offered both unexpectedly interesting structure and properties.

Supplementary Materials: The following are available online at http:/ / www.mdpi.com/2073-4352/8/11/415/s1, Figure S1. X-ray powder diffraction data of $\mathbf{1 a}$ and $\mathbf{1 b}$ (red line: calculation, black line: experiment); Figure S2. Thermogravimetric analysis for complex 1a was carried under nitrogen atmosphere at a heating rate of $10 \mathrm{~K} / \mathrm{min}$; Figure S3. Showing the closet approach between $\mathrm{Fe}(2)$ centers for $\mathbf{1 b}$ at $90 \mathrm{~K}$.

Author Contributions: Data curation, I.T.; Formal analysis, D.A. and T.S.; Investigation, T.K. and I.T.; Project administration, T.K.; Supervision, T.K.

Funding: This work was financially supported by KAKENHI (JSPS/15K05485 and 18K04964) and the Yashima Environment Technology Foundation. Part of this work was supported by the Ministry of Education, Culture, 
Sports, Science, and Technology, Japan (MEXT)-Supported program for the Strategic Research Foundation at Private Universities 2012-2016.

Conflicts of Interest: The authors declare no conflict of interest.

\section{References}

1. Real, J.A.; Andrés, E.; Munoz, M.C.; Julve, M.; Granier, T.; Bousseksou, A.; Varret, F. Spin crossover in a catenane supramolecular system. Science 1995, 268, 265-268. [CrossRef] [PubMed]

2. Miyamachi, T.; Gruber, M.; Davesne, V.; Bowen, M.; Boukari, S.; Joly, L.; Scheurer, F.; Rogez, G.; Yamada, T.K.; Ohresser, P.; et al. Robust spin crossover and memristance across a single molecule. Nat. Commun. 2012, 3, 938. [CrossRef] [PubMed]

3. Gentili, D.; Givaja, G.; Mas-Ballesté, R.; Azani, M.-R.; Shehu, A.; Leonardi, F.; Mateo-Martí, E.; Greco, P.; Zamora, F.; Cavallini, M. Patterned conductive nanostructures from reversible self-assembly of 1D coordination polymer. Chem. Sci. 2012, 3, 2047-2051. [CrossRef]

4. Gentili, D.; Demitri, N.; Schäfer, B.; Liscio, F.; Bergenti, I.; Ruani, G.; Ruben, M.; Cavallini, M. Multi-modal sensing in spin crossover compounds. J. Mater. Chem. C 2015, 3, 7836-7844. [CrossRef]

5. Gütlich, P.; Garcia, Y.; Goodwin, H.A. Spin crossover phenomena in Fe(ii) complexes. Chem. Soc. Rev. 2000, 29, 419-427. [CrossRef]

6. Chiruta, D.; Jureschi, C.-M.; Linares, J.; Garcia, Y.; Rotaru, A. Lattice architecture effect on the cooperativity of spin transition coordination polymers. J. Appl. Phys. 2014, 115, 053523. [CrossRef]

7. Kitazawa, T.; Gomi, Y.; Takahashi, M.; Takeda, M.; Enomoto, M.; Miyazaki, A.; Enoki, T. Spin-crossover behaviour of the coordination polymer FeII $\left(\mathrm{C}_{5} \mathrm{H}_{5} \mathrm{~N}\right)_{2} \mathrm{Ni}^{\mathrm{II}}(\mathrm{CN})_{4}$. J. Mater. Chem. 1996, 6, 119-121. [CrossRef]

8. Galet, A.; Muñoz, M.C.; Martinez, V.; Real, J.A. Supramolecular isomerism in spin crossover networks with aurophilic interactions. Chem. Commun. 2004, 2268-2269. [CrossRef] [PubMed]

9. Muñoz, M.C.; Gaspar, A.B.; Galet, A.; Real, J.A. Spin-Crossover Behavior in Cyanide-Bridged Iron(II)-Silver(I) Bimetallic 2D Hofmann-like Metal-Organic Frameworks. Inorg. Chem. 2007, 46, 8182-8192. [CrossRef] [PubMed]

10. Agustí, G.; Muñoz, M.C.; Gaspar, A.B.; Real, J.A. Spin-Crossover Behavior in Cyanide-bridged Iron(II)-Gold(I) Bimetallic 2D Hofmann-like Metal-Organic Frameworks. Inorg. Chem. 2008, 47, 2552-2561. [CrossRef] [PubMed]

11. Kosone, T.; Kachi-Terajima, C.; Kanadani, C.; Saito, T.; Kitazawa, T. A two-step and hysteretic spin-crossover transition in new cyano-bridged hetero-metal $\mathrm{Fe}^{\mathrm{II}} \mathrm{Au}^{\mathrm{I}}$ 2-dimensional assemblage. Chem. Lett. 2008, 37, 422-423. [CrossRef]

12. Kosone, T.; Kanadani, C.; Saito, T.; Kitazawa, T. Synthesis, crystal structures, magnetic properties and fluorescent emissions of two-dimensional bimetallic coordination frameworks $\mathrm{Fe}^{\mathrm{II}}$ (3-fluoropyridine) 2 $\left[\mathrm{Au}^{\mathrm{I}}(\mathrm{CN})_{2}\right]_{2}$ and $\mathrm{Mn}^{\mathrm{II}}$ (3-fluoropyridine $)_{2}\left[\mathrm{Au}^{\mathrm{I}}(\mathrm{CN})_{2}\right]_{2}$. Polyhedron 2009, 28, 1930-1934. [CrossRef]

13. Kosone, T.; Kanadani, C.; Saito, T.; Kitazawa, T. Spin crossover behavior in two-dimensional bimetallic coordination polymer Fe ${ }^{\mathrm{II}}$ (3-bromo-4-picoline $)_{2}\left[\mathrm{Au}^{\mathrm{I}}(\mathrm{CN})_{2}\right]_{2}$ : Synthesis, crystal structures, and magnetic properties. Polyhedron 2009, 28, 1991-1995. [CrossRef]

14. Kosone, T.; Tomori, I.; Kanadani, C.; Saito, T.; Mochida, T.; Kitazawa, T. Unprecedented three-step spin-crossover transition in new 2-dimensional coordination polymer $\left\{\mathrm{Fe}^{\mathrm{II}}(4 \text {-methylpyridine })_{2}\left[\mathrm{Au}^{\mathrm{I}}(\mathrm{CN})_{2}\right]_{2}\right\}$. Dalton Trans. 2010, 39, 1719-1721. [CrossRef] [PubMed]

15. Okabayashi, J.; Ueno, S.; Kawasaki, T.; Kitazawa, T. Ligand 4-X pyridine $(\mathrm{X}=\mathrm{Cl}, \mathrm{Br}, \mathrm{I})$ dependence in Hofmann-type spin crossover complexes: Fe(4-Xpyridine $)_{2}\left[\mathrm{Au}(\mathrm{CN})_{2}\right]_{2}$. Inorg. Chim. Acta 2016, 445, 17-21. [CrossRef]

16. Kosone, T.; Kawasaki, T.; Tomori, I.; Okabayashi, J.; Kitazawa, T. Modification of Cooperativity and Critical Temperatures on a Hofmann-Like Template Structure by Modular Substituent. Inorganics 2017, 5, 55. [CrossRef]

17. Sheldrick, G.M. SADABS, Program for Empirical Absorption Correction for Area Detector Data; University of Göttingen: Göttingen, Germany, 1996.

18. Sheldrick, G.M. SHELXL, Program for the Solution of Crystal Structures; University of Göttingen: Göttingen, Germany, 1997. 
19. Kosone, T.; Kitazawa, T. Guest-dependent spin transition with long range intermediate state for 2-dimensional Hofmann-like coordination polymer. Inorg. Chim. Acta 2016, 439, 159-163. [CrossRef]

20. Kawasaki, T.; Kachi-Terajima, C.; Saito, T.; Kitazawa, T. Triply Interpenetrated Structure of $\left\{\mathrm{Mn}^{\mathrm{II}}(\mathrm{L})_{2}\right.$ $\left.\left[\mathrm{Ag}^{\mathrm{I}}(\mathrm{CN})_{2}\right]_{2}\right\}\left\{\mathrm{Mn}^{\mathrm{II}}\left(\mathrm{H}_{2} \mathrm{O}\right)_{2}\left[\mathrm{Ag}^{\mathrm{I}}(\mathrm{CN})_{2}\right]_{2}\right\}(\mathrm{L}=4-\mathrm{CNpy}$ or py-4-aldoxime). Bull. Chem. Soc. Jpn. 2008, 81, 268-273. [CrossRef] 